\title{
Factors Affecting Emotional Intelligence Levels in Medical Trainees: Should All Trainees Undertake a Gap Year? [Letter]
}

This article was published in the following Dove Press journal: Advances in Medical Education and Practice

\author{
Reem Moussa' \\ Ebtehal Moussa ${ }^{2}$ \\ 'St George's University of London, \\ London, UK; ' ${ }^{2}$ University of Buckingham, \\ Buckingham, UK
}

\section{Dear editor}

We read with interest the article by Shahid and Adams ${ }^{1}$ discussing the effects of time off before commencing medical school on emotional intelligence (EI). The authors concluded that EI was greater in those who had taken a gap year regardless of age, gender or type of medical degree. We feel that EI is important to help doctors manage stressful working environments and wanted to address certain aspects of the paper that we believe should be taken into consideration.

Firstly, residents were asked whether they took time off before medical school to work, carry out research or obtain an advanced degree; however EI of these trainees were not directly compared against each other. This means that it is difficult to determine which factor affects EI the most. Furthermore, the study does not account for other activities carried out during gap years such as travel or physical activity - which have been shown to increase EI. ${ }^{2}$ Assuming that gap years alone increase EI is perhaps too simplistic a hypothesis as it could be the activity undertaken that increases EI.

Moreover, the authors argue that there was no association between age and EI. These results are confounded by Joseph et al, ${ }^{3}$ who found a statistically significant increase in EI in medical students aged 22 years or above compared to all younger students $(p=0.04)$, thus highlighting that normal aging may be a greater factor than the gap year itself. The authors reasoned that during a gap year 'working with a diverse group of people leads to improved communication and relationship building' - however this can also be achieved during medical school itself. Once again, this indicates that perhaps the activity carried out during the gap year is of greater influence on EI development.

Of note, this research was carried out on trainees: thus the scores achieved may not necessarily reflect the effects of a gap year, but rather all the experience gained throughout medical school. Although the paper discussed that type of medical school did not affect EI, some medical schools emphasise problem-based learning, oral examinations and reflective practise, all of which can increase EI. This means that further research is required to inform medical schools of the best methods of delivering teaching such that universities are aware of how to aid students in developing EI. Utilising the knowledge of what students carried out during their
Correspondence: Reem Moussa St George's University of London, London, UK

Email reemgmoussa@hotmail.co.uk
Advances in Medical Education and Practice 2020:1/ 76I-762 
gap year can give universities insight into what should be incorporated into the curriculum.

The authors may wish to consider the effects of undertaking an intercalated degree or taking interruption of study during medical school. Both include taking some time off to pursue other interests and can lead to students working with different groups of people and increasing EI. ${ }^{4,5}$

Nonetheless, this research informs universities that gap years produce more EI doctors, meaning that students may wish to consider undertaking a gap year should they wish to strengthen their application. It also informs universities that there is perhaps a gap in the teaching that should be filled to reduce this discrepancy.

\section{Disclosure}

The authors report no conflicts of interest for this communication.

\section{References}

1. Shahid R, Adams W. Emotional intelligence level higher in residents who took a gap year before medical school. Adv Med Educ Pract. 2020;11:559-562. doi:10.2147/AMEP.S268464

2. Tsaousis I, Nikolaou I. Exploring the relationship of emotional intelligence with physical and psychological health functioning. Stress Health. 2005;21(2):77-86. doi:10.1002/smi.1042

3. Joseph N, Panicker V, Nelliyanil M, Jindal A, Viveki R. Assessment and determinants of emotional intelligence and perceived stress among students of a medical college in south India. Indian J Public Health. 2015;59(4):310-313. doi:10.4103/0019-557X.169666

4. Graham B, Elbeltagi H, Nelmes P, Jenkin A, Smith J. What difference can a year make? Findings from a survey exploring student, alumni and supervisor experiences of an intercalated degree in emergency care. BMC Med Educ. 2019;19(1):188. doi:10.1186/s12909-0191579-x

5. Agha R, Fowler A, Whitehurst K, Rajmohan S, Gundogan B, Koshy K. Why apply for an intercalated research degree? International journal of surgery. Oncology. 2017;2(6):e27. doi:10. 1097/IJ9.0000000000000027

\begin{abstract}
Dove Medical Press encourages responsible, free and frank academic debate. The content of the Advances in Medical Education and Practice 'letters to the editor' section does not necessarily represent the views of Dove Medical Press, its officers, agents, employees, related entities or the Advances in Medical Education and Practice editors. While all reasonable steps have been taken to confirm the content of each letter, Dove Medical Press accepts no liability in respect of the content of any letter, nor is it responsible for the content and accuracy of any letter to the editor.
\end{abstract}

Advances in Medical Education and Practice

\title{
Dovepress
}

\section{Publish your work in this journal}

Advances in Medical Education and Practice is an international, peerreviewed, open access journal that aims to present and publish research on Medical Education covering medical, dental, nursing and allied health care professional education. The journal covers undergraduate education, postgraduate training and continuing medical education including emerging trends and innovative models linking education, research, and health care services. The manuscript management system is completely online and includes a very quick and fair peer-review system. Visit http://www.dovepress.com/testimonials.php to read real quotes from published authors. 